\title{
Tacking Toward Justice
}

\section{Citation}

Levinson, Meira. 2013. “Tacking Toward Justice." Edited by Margaret Dancy, Victoria Costa, and Joshua Gert. Social Theory and Practice 39 (2): 343-352. doi:10.5840/soctheorpract201339219.

\section{Published Version}

doi:10.5840/soctheorpract201339219

\section{Permanent link}

http://nrs.harvard.edu/urn-3:HUL.InstRepos:12701476

\section{Terms of Use}

This article was downloaded from Harvard University's DASH repository, and is made available under the terms and conditions applicable to Open Access Policy Articles, as set forth at http:// nrs.harvard.edu/urn-3:HUL.InstRepos:dash.current.terms-of-use\#OAP

\section{Share Your Story}

The Harvard community has made this article openly available.

Please share how this access benefits you. Submit a story.

\section{Accessibility}




\section{Tacking Toward Justice}

\section{Review of M. Victoria Costa (2011). Rawls, Citizenship, and Education. Routledge. \\ Meira Levinson, Harvard Graduate School of Education Reviewed for Social Theory and Practice 39(2), 2013.}

Anyone who wants to understand either the role that Rawls himself considered education to play within his political theory, or the most plausible philosophy of civic education that could be constructed with a Rawlsian political framework, must read M. Victoria Costa's clear and compelling book, Rawls, Citizenship, and Education (Routledge, 2011). Costa provides an indispensable synthetic roadmap to Rawls' writings about social justice, education, and civic stability. She shows how and why education of children is essential for the achievement and maintenance of a just state from a Rawlsian perspective. She discusses both the theoretical justifications for and the practical import of education in the context of families, schools, and political institutions themselves, exemplifying a welcome systemic approach to civic education. In doing so, Costa tacks deftly between Rawls' ideal theory and the non-ideal concerns that inevitably arise when one is considering contemporary policy questions. In this respect, as in many others, she is a supremely sympathetic but not deferential reader of Rawls. It is a maddening fact of Rawls that he barely mentions either education or schools in his work, and when he does, he makes suggestions that seem at odds with other parts of his theory. It would be easier if he had said nothing; then political theorists and philosophers of education could have constructed a plausible account on their own. Rawls, however, says just enough to stymie philosophers who want to develop a coherent and appealing Rawlsian theory of education. Costa navigates these treacherous waters by sticking to Rawls as closely as she can, but also making additions-such as freedom as non-domination-and divergences - such as her acknowledgment that education is necessarily more than a minimal enterprise-as needed. This approach is well considered, and positions Rawls, Citizenship, and Education as an important book in illuminating how political justifications can support a robust statesponsored program of civic education.

Another welcome feature of Rawls, Citizenship, and Education is its ability to speak to both lay and expert audiences simultaneously. Costa is a dedicated scholar of Rawls. She summarizes and synthesizes his corpus in admirable fashion. In so doing, she provides an accessible roadmap to his work for non-specialists. Students and scholars in fields other than political theory can easily learn from Costa about the essential features of Rawls' theory of justice, both in general and as it applies to education. At the same time, Costa navigates the shifts between Rawls' earlier and later works in a way that experts in the field will appreciate. She is transparent about where her interpretations of Rawls converge with others' and where and how they move in new directions. She's appropriately unapologetic about rising above the minutiae of competing Rawlsian interpretations in order to develop her own, original account of civic education within a Rawlsian framework.

After offering a brief introduction in Ch. 1, Costa begins by summarizing Rawls' theory of social justice in Chs. 2 and 3. This is where she establishes herself as a highly sympathetic but not slavish follower of Rawls. She addresses a number of critiques in order to hew closely to Rawls' political theory. But she herself argues that his account of how states can achieve "a deep and widespread moral consensus on 
the principles of justice" through only minimal regulation of education "is too optimistic" and "needs to be supplemented by a more substantial account of the role of educational institutions" (p. 37). This leads her in Ch. 4 to evaluate the family as an educative institution, as well as more generally as a component of the "basic structure" of society that is supposed to promote social justice. Costa's analysis is complex-even at times intellectually convoluted-as she tries to justify Rawls' embrace of the family as a social institution that forms the basic structure of society despite the patently unjust dimensions of both intrafamily and interfamilial life. Although she never directly says so, it appears from this chapter and Ch. 5, in which she directly addresses schools as educative institutions, that she wishes that Rawls had included schools in, and excluded families from, the basic structure. Costa is too eager to remain an interpreter rather than a rewriter of Rawls to be so blunt about where he got his own theory wrong. I am convinced by many of her arguments, however, that schools are necessary tools for achieving stable and just societies, and at least in an ideal context can be regulated so as to instantiate as well as to teach social justice, whereas families are likely both to instantiate and to exacerbate injustice even in ideal contexts, let alone in non-ideal worlds.

In any case, Costa mostly confines her analysis to schools in the second half of the book, focusing especially on what kind of civic education is both necessary and sufficient to support social justice. Chapters 6, 7, and 8 take up different aspects of the curriculum, beginning in Ch. 6 with the education of "free and equal citizens," which she reinterprets as education for non-domination, or education against servility. Costa argues that such an education aims to teach toleration, mutual respect, the burdens of judgment, and even mutually sympathetic analysis of diverse conceptions of the good. I found Costa's arguments in favor of this decidedly non-minimal curricular agenda generally convincing. Ch. 7 rejects the idea that patriotic education, at least understood in a nationalist sense, is either necessary or desirable; instead, she argues in favor of teaching about the desirability of the principles of justice themselves. These arguments reinforce the educational agenda she introduced in previous chapters, while also emphasizing the importance of teaching children about principles. This chapter is the most convincing educational analysis in the book; not coincidentally, it also plunges most deeply into the details of educational practice and policy. Ch. 8 argues in favor of multicultural education that teaches children to respect and accommodate not only competing comprehensive conceptions of the good but also multiple cultural and other expressions of diversity. Again, this chapter expands upon some of her earlier points about the importance of teaching children to understand and analyze actual belief systems and ways of life, not just abstract notions of tolerance and mutual respect. She then offers brief concluding remarks in Ch. 9.

As I move from summary to critique, let me admit upfront that I am not a Rawlsian, and hence I find it somewhat difficult to assess the success of Costa's interpretive enterprise. For example, I believe that Rawls' simplifying assumptions, which Costa does a nice job of teasing out, turn his ideal theory into an isolated edifice; it may be beautiful to look at, but it is far too removed from the challenges of contemporary societies to function as a guide for real-world action. I also think that the fact that Rawls' political justification of particular educational aims (e.g. teaching the burdens of judgment) in practice has substantive consequences for the kinds of comprehensive conceptions that children will be able to hold is in itself a central problem for Rawls' theory (Levinson 1999). Costa agrees that the educational 
"content" of justice as fairness is virtually indistinguishable from the educational content of perfectionist liberal theories. "Rawls' own attempts to distinguish his view from more comprehensive liberalisms by pointing to differences in educational policy fail" (p. 65). She nonetheless argues that because "the sorts of arguments employed to justify" these educational consequences are different, a Rawlsian educational theory is more attractive and more stable, because it's merely political, than is perfectionist liberal educational theory (p. 65). I'm unconvinced. I see no reason for parents to sign onto an educational program that will prevent their children from living lives they value just because the arguments in favor of this education are political rather than comprehensive. On the flip side, if the Rawlsian educational program Costa lays out is successful, I don't see how the distinction between political and comprehensive justifications will matter after the first generation. All children who receive the full dose of Costa's civic education curriculum will, if the curriculum works, grow up to be comprehensive liberals. If the curriculum doesn't work, then even Rawls' political liberal society is at risk from illiberal childrenturned-adults who reject its basic premises and threaten its stability. In these respects, I am sympathetic to many of the critiques of Rawls that Costa attempts to counter in her book, and unconvinced by some of her responses.

I don't think it's helpful to critique Costa's fine book, however, from a standpoint that is profoundly skeptical of Rawls. Her purpose is not to defend a Rawlsian theory of education against competing political theories of education, but instead to develop an attractive theory of education that is compatible with Rawlsian principles. Given this, I will try in the rest of this review to evaluate Costa's arguments on their own terms. I will take her analysis of Rawls' political theory as a given, and in general confine my assessment to the conclusions she draws about education. There will be some moments when my critique of Costa has knock-on effects for Rawls' theory itself-most notably with respect to Costa's rather schizophrenic tack between ideal versus non-ideal theory. I shall suggest this schizophrenia reveals a lack of clarity in Rawls' own theory construction. But for the most part, I will try to remain within a Rawlsian framework, as Costa herself does.

I was both convinced and frustrated by many of the quite specific policy prescriptions that Costa derives from Rawls' theory. Costa herself seems to regard these prescriptions as some of the key contributions of the book, but I wish she spent more time fleshing them out both from a theoretical standpoint and with regard to their empirical implementation.

At the end of Ch. 4, for example, Costa claims that "taking seriously the ideal of equal citizenship favors equalizing expenditure per student...Of course, some additional resources should be allocated to students with special needs, to compensate for disabilities or social disadvantages" (p. 54). I am sympathetic to this policy stance, but she derives it astonishingly quickly, leaving aside enormous questions. Most importantly, I'm curious whether she thinks that equal citizenship is satisfied truly by equal expenditures on each student (adjusting for special needs), or whether she in fact has in mind equal educational outcomes. There is overwhelming data from the U.S. and abroad that schools and districts with equal levels of expenditures have vastly different but also highly predictable outcomes for their students, based on the incoming characteristics of students, the quality of teachers they are able to purchase (depending on rural versus suburban or urban location, competition with nearby districts, reputation, etc.), their educational priorities (academics vs. vocational education, test prep versus 
inquiry-based education, arts and music versus sports), and other factors. In order to defend a policy of equal expenditures rather than equal outcomes, at least some of these differences must be acceptable sources of variation from Costa's Rawlsian perspective. I'd be curious which ones. For example, is it okay for a child to be less likely to attend a selective college because her town democratically chose to spend money on refurbishing the football stadium rather than on hiring AP science teachers? What about differences in educational outcomes that are attributable to peer effects? Consider one child who is in a school that serves children who "do school" well, while another equally talented and motivated child attends a school that has a less stable student population who are also less academically successful. Data clearly demonstrate that the first child is likely to have higher educational attainment than the second. Are these unequal outcomes acceptable? Given Costa's embeddedness within Rawlsian theory, she has excellent reasons to resist an outcome-based funding scheme, but the policy prescriptions she derives are significantly undertheorized in response to real-world dilemmas.

Furthermore, the mismatch between equal school funding and equal educational outcomes matters in particular for Rawls (and hence for Costa) because education is not only an absolute good but also a positional good (Nie et al. 1996). Young people striving for many jobs now need a college degree not because the job itself demands college-level knowledge or skills, but because there's a surfeit of applicants who can boast such a degree. Access to powerful social and political networks is also increasingly predicated on relative educational attainment, with "mere" college graduates excluded from networks now accessible only through professional school attendance at selective institutions. It's not my purpose here to rehash the important educational equality versus adequacy debates of the past decade (Reich and Koski 2006; Anderson 2007; Satz 2007). But I do want to point out why this question of whether equal educational expenditures or attainment is really what matters is of such significance to Costa's account of Rawlsian education policy. Costa notes that, "Rawls claims that equality in the rights and liberties of citizens is consistent with significant inequality in the resources citizens have.....In order to challenge this claim, one would have to show that Rawls' theory fails to protect in some important respect the status of citizens as free and equal. One way to do this would be to try to show that the non-political basic liberties have some comparative or relational aspect in the same way that the political ones do: that one's position relative to others is relevant in terms of the extent to which one can enjoy all the basic liberties characteristic of free citizens" (p. 77). My contention is that educational attainment poses this exact challenge: one's educational achievement relative to others indubitably influences the extent to which one can enjoy all the basic liberties characteristic of free citizens.

On a different note with regard to equal educational expenditures, I'm curious what position Costa would take on the permissibility of voluntary educational expenditures by parents or local businesses that top up the otherwise equal funding a school or district receives from the state. As Rob Reich has shown (Reich 2005), some districts in California are able to virtually double the average state per-pupil expenditure thanks to a wealthy parent donor base. They use this money to fund science and arts teachers, field trips, reading specialists, clubs and teams, and all sorts of opportunities that children in poorer districts don't receive. Equal funding is hence honored only in the breach. Furthermore, Reich has suggested that because such donations are legal, wealthy parents have little incentive to get involved politically to advocate for higher overall state funding for schools, thus exacerbating California's 
precipitous educational collapse. Given these considerations, do private donations to public schools violate equal citizenship? If so, would Costa put a stop to such donations? Answers to these questions also have to take into account the implications for families' differential expenditures on enrichment opportunities at home. It's clear that neither Rawls nor Costa believes it would be appropriate for the state to interfere in families' personal expenditures on their own children. But then it would seem foolish to prohibit families' expenditures on other people's children. Arguably, donations to the school equalize opportunity to some extent by giving all children at the school access to the educational goods and services, whereas private expenditures benefit only the family's children themselves. Costa may well reply that for precisely these reasons, she favors private donations to particular schools and districts-but that still leaves her policy prescriptions for "equal educational funding" in question when state expenditures on schools constitute only a fraction of total educational expenditures.

Another question that I wish Costa had addressed is homeschooling. Costa argues that while "a significant portion of a child's education takes place in a family....an equally significant portion of a child's education takes place in school, and this portion can be subject to public regulation and control without jeopardizing the important functions of families" (p. 52). She relies on this latter fact to justify the inequities that result from family control as well as to justify the merely "threshold" expectations for the kind of civic education families should provide. These arguments may be satisfactory if all children go to school. But Costa is silent about whether or not school attendance should be required. As of 2007, about 1.5 million children in the U.S. were being homeschooled (U.S. Department of Education 2009). Should this be disallowed under a Rawlsian framework (see Reich 2002)? If not, how can we be assured that children are being treated like equal citizens, or that citizens will grow up to support the principles of justice?

Related questions beg to be addressed in her chapter on multicultural education. Costa rightly, if relatively uncontroversially, comes out in favor of providing equal educational opportunities to minority children, and also to educating majority children about the virtues and contributions of minority cultures. She contends that schools should make accommodations "so as to make students of different cultural backgrounds feel as welcome and as comfortable as possible" (p. 123); they should also teach a multicultural curriculum and even support bilingual education. I am in favor of this as a matter of educational policy, but can't imagine that Rawls' ideal theory really supports getting in the weeds like this, nor do I think his theory automatically comes down on the side of lefty educational policies, as Costa continually seems to assume. More to the point, Costa focuses on happy-feeling curricula while ignoring structural and institutional questions. I am dying to know if Costa would support voluntary separate schools, and what her justifications for or against would be. What if such schools demonstrably increased opportunity and reduce inequality?

Costa's policy prescriptions for how schools can help children resist domination are also attractive as far as they go, but cry out for further exploration. Costa argues that while education for autonomy is controversial, "one can expect much wider agreement on the claim that domination is prima facie bad and that there are good reasons to avoid or prevent it....The reasonable expectation of widespread agreement regarding the badness of domination allows the case for the education for freedom as nondomination to be framed within the boundaries of political justification," and hence to find support in a 
Rawlsian theory (p. 86). She argues that civic education can reduce citizens' risk of being dominated both by spreading personal virtues "as aids to the rule of law" (p. 88) and by "encouraging children to think of themselves as equal to others and therefore entitled to respectful treatment" (p. 88). She emphasizes that boys and girls of all ethnicities should be taught to view themselves as equals, and hence also "as entitled to form their own plans and to pursue them" (p. 90). As with her other curricular recommendations, I embrace the content of these lessons. I remain dubious, however, that the political (anti-domination) justification for this kind of education will be any more attractive to non-autonomy favoring parents and citizens than a perfectionist justification would be.

Even if domination itself is widely agreed to be bad, I anticipate widespread contention over whether and how children should be taught to resist domination by adults. Both schooling and family life are often predicated on adults' domination of children. Youth are absolutely not treated as deserving of respect equal to their teachers and parents; in fact, claims of equality or self-direction are treated as threatening the very core of the educational and child-rearing enterprises (I discuss this in Levinson 2012: Ch. 5). To take one recent example, the 2012 Texas Republican Party platform includes the following plank: "We oppose the teaching of Higher Order Thinking Skills (HOTS) (values clarification), critical thinking skills and similar programs that are simply a relabeling of Outcome-Based Education (OBE) (mastery learning) which focus on behavior modification and have the purpose of challenging the student's fixed beliefs and undermining parental authority" (Republican Party of Texas 2012). While many on the left (or living on the coasts) may deride Texas Republicans as backwards reactionaries, it's important to recognize that even the most progressive parents and educators who believe that young people should be encouraged to think of themselves as equals entitled to respect likely still end up dominating children "for their own good" on a frequent basis. Costa's definition of domination, following Philip Pettit, specifies that it exists "whenever one agent has the capacity to interfere at will and with impunity in some of the choices and actions of another" (p. 87). This structural relationship clearly pertains to adults and children both in the home and at school-and it pertains in Ann Arbor and Palo Alto as much as in Dallas or Lubbock.

Finally, I want to address Costa's decision to move back and forth between ideal and non-ideal theory in developing her account of Rawlsian education policies. The task that Costa set herself is to determine the contours of education policy that is compatible with-and even helps to realize-Rawlsian principles. But Rawls' theory specifically discourages the derivation of policy implications as such. Rawls himself insists that his theory is about the "basic structure" of society alone, not about specific arrangements that may be made in particular societies with respect to tax systems, particular market regulations, and the like. Furthermore, because Rawls' theory is constructed within an ideal frame, buttressed by a number of simplifying assumptions, it has a very imperfect match with any real-world contexts in which one would set policy. Costa herself emphasizes in the first half of the book that all of the elements of the basic structure are designed to work together to promote justice as fairness. A full and equal complement of political rights, for example, may do little to advance justice if access to the powers and prerogatives of offices and social bases of self-respect, say, are unfairly distributed. From this perspective, whether or not schools should truly be considered (contra Rawls) as part of the basic structure of society, their roles and what they teach should be analyzed solely in light of other 
institutions' functioning appropriately and in line with the demands of justice. Costa occasionally confines her educational analysis to such fully ideal settings. But she rightly finds these restrictions unsatisfying. Hence, Costa often finds herself in the awkward position of trying to derive from Rawls' ideal theory specific educational policy recommendations-about the content of civic education, say, or the kinds of accommodations that should be made for cultural minorities-for a non-ideal context, reflective of at least some aspects of the real work in which we live, in which the basic structure of society does not align with the demands of justice as fairness. This leads to some of the intellectual contortions I alluded to above-and which leave me wondering whether we' $\mathrm{d}$ be better off starting from non-ideal theory in the first place.

Costa's inclination toward non-ideal theorizing is understandable with regard not only to the non-ideal context of any policy prescriptions, but especially to the special challenge posed by children. Children's upbringing is particularly difficult to address in ideal theory because they are decidedly non-ideal beings. They haven't already accepted the burdens of judgment (these burdens don't even make sense to them for many years), or agreed to live in harmony with others. They often behave unreasonably and even irrationally, and they are easily induced by those they love to embrace beliefs and ways of life that are nonsensical and threatening to outsiders. Especially if it is acknowledged that they may be raised in families that are out of accord with liberal political principles, they are truly "strangers in a strange land" whose non-ideal presence necessarily intrudes upon the ideal world. These characteristics of children perhaps explain why Rawls spends so little time addressing them in his theory-although of course even his most ideal society requires a constant influx of children for its perpetuation. In Rawls, Citizenship, and Education, Costa admirably strives to address children's presence within a(n imperfectly) just world, and to explore what it would take to equip them to foster a Rawlsian conception of justice themselves. Even when her answers and approaches diverge from Rawls' own, she provides a thoughtful and compelling roadmap to education in service of civic equality and the achievement of a more just society.

\section{References}

Anderson, Elizabeth (2007). "Fair Opportunity in Education: A Democratic Equality Perspective." Ethics 117(4): 595-622.

Levinson, Meira (1999). The Demands of Liberal Education. Oxford, Oxford University Press. Levinson, Meira (2012). No Citizen Left Behind. Cambridge, MA, Harvard University Press. Nie, Norman H., Jane Junn and Kenneth Stehlik-Barry (1996). Education and Democratic Citizenship in America. Chicago, Chicago University Press.

Reich, Rob (2002). "Testing the Boundaries of Parental Authority Over Education: The Case of Homeschooling." Political and Moral Education, NOMOS XLIII. Stephen Macedo and Yael Tamir, eds. New York, New York University Press: 275-313.

Reich, Rob (2005). "A Failure of Philanthropy: American Charity Shortchanges the Poor, and Public Policy is Partly to Blame." Stanford Social Innovation Review(Winter): 24-33.

Reich, Rob and William S. Koski (2006). "When Adequate Isn't: The Retreat From Equity in Educational Law and Policy and Why it Matters." Emory Law Review 56(3).

Republican Party of Texas (2012). "2012 Republican Party of Texas Report of Platform Committee: 2012 State Republican Party Platform." Austin, TX, Republican Party of Texas. Retrieved July 24, 2012, from http://s3.amazonaws.com/texasgop pre/assets/original/2012Platform Final.pdf

Satz, Debra (2007). "Equality, Adequacy, and Education for Citizenship." Ethics 117(4): 623-648. 
U.S. Department of Education, National Center for Education Statistics. (2009). "The Condition of Education 2009 (NCES 2009-081), Indicator 6." Retrieved July 24, 2012, from http://nces.ed.gov/programs/coe/indicator hsc.asp. 